\title{
Clinicopathological and immunohistochemical correlations of breast carcinoma with vitamin D status in Erbil Governorate, Kurdistan of Iraq
}

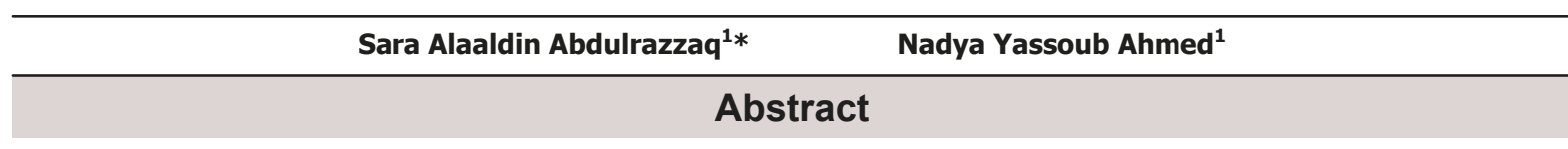

Background and objective: Vitamin $D$ has been associated with decreased risk of several cancers, including breast cancer, and its deficiency has been associated with poor prognosis. This study evaluated vitamin $\mathrm{D}$ level in breast cancer patients at diagnosis and investigated its association with various breast cancer prognostic criteria, especially the intrinsic molecular subtypes.

Methods: Using a prospective population-based, case-control and case series, study in Erbil city during $1^{\text {st }}$ October 2017 and $31^{\text {st }}$ March 2018, we evaluated vitamin D status in 50 breast cancer patients in correlation with 100 normal healthy controls. We examined various clinicopathological and immunohistochemical features of breast cancer to determine the prognostic effect of plasma 25-hydroxyvitamin D levels at diagnosis.

Results: The mean patient's age was $51.1 \pm 10.7$ years. The mean plasma 5-hydroxyvitamin $D$ concentration was $8.138 \pm 7.5$ and $16.7 \pm 12.06 \mathrm{ng} / \mathrm{mL}$ in the breast cancer patients and controls, respectively $(P<0.001)$. Vitamin $\mathrm{D}$ deficiency was associated with positive breast cancer risk (Odds Ratio (OR), 4.1; 95\% confidence interval $(\mathrm{Cl})$, $1.68-10)$. The risk was greater in premenopausal $(\mathrm{OR}=7.5 ; 95 \% \mathrm{Cl}=1.60-35.23)$ than postmenopausal women $(\mathrm{OR}=2.7 ; 95 \% \mathrm{Cl}=0.87-8.49)$. The mean serum level of 5-hydroxyvitamin $D$ decreased significantly with the increasing stage in premenopausal $(P=0.055)$ and HER2/neu +ve immunoexpression $(P=0.008)$, especially in postmenopausal $(P=0.035)$. Regarding the molecular subtypes, HER2/neu enriched type showed the lowest mean 5-hydroxyvitamin $D$ with a significant statistical association in premenopausal $(P=0.033)$.

Conclusion: These results add to a growing body of evidence that vitamin $D$ deficiency associated with breast cancer risk and prognosis. Well-designed clinical trials are highly needed to determine whether vitamin $D$ supplementation is effective for breast cancer chemoprevention and prognosis improvement if occur.

Keywords: Breast cancer; Molecular types; Vitamin D.

\section{Introduction}

Both globally and locally, breast cancer is the most common cancer among women, comprising $23 \%$ of the female cancers and it is also the leading cause of cancer-related deaths. ${ }^{1-3}$ Due to the magnitude of this disease, considerable research effort has been directed toward identifying breast cancer risk factors to target them for prevention and decreasing the incidence as genetic mutation, reproductive factors, family history, breast density, increasing age, and nutritional risk factors. ${ }^{4}$ However, relatively few modifiable lifestyle and environmental factors have been associated with reduced breast cancer risk. Chemoprevention refers to altering the carcinogenesis process with drug intervention. The antiestrogens, tamoxifen, and raloxifene, are the only drugs that have been approved by the US Food and Drug Administration for breast cancer prevention in high-risk populations. Due to serious toxicities associated with

${ }^{1}$ Department of Pathology, College of Medicine, Hawler Medical University, Erbil, Iraq

* Correspondence: sara.histo@gmail.com 
these agents, namely endometrial cancer and thromboembolic disease, they have not gained widespread acceptance in the primary prevention setting. In addition, these antiestrogens do not lower the incidence of more aggressive estrogen receptor (ER)-negative breast cancers, which account for about one third of all breast tumors and are associated with a poorer prognosis compared with ER-positive cancer. ${ }^{5}$ In the cancer research field, vitamin $D$ has emerged as the most prolific topic in the last decade with work connecting it with risk reduction in various epithelial cancers, of particular is the reduced incidence of breast, colon, and prostate cancers with higher sun exposure, higher intake, or higher serum levels of vitamin $D^{6,7}$ In the cancer research field, vitamin $D$ has emerged as the most prolific topic in the last decade with work connecting it with risk reduction in various epithelial cancers. Aside from calcium homeostasis, vitamin $D$ exerts a wide range of immunogenic and antiproliferative activities in the body. Of particular interest to the oncologists is the reduced incidence of breast, colon, and prostate cancers with higher sun exposure, higher intake, or higher serum levels of vitamin $D .^{8}$ Activated vitamin $D$ exerts its antitumor effects via the vitamin $D$ receptor to form a nuclear receptor-ligand complex, which regulates the expression of target genes such as $p 21, p 27, c$-fos, and $c$-myc that encode for proteins important in the regulation of cell proliferation, differentiation, apoptosis, and angiogenesis. This makes the effect of vitamin $D$ in breast cancer biologically plausible as suboptimal level may impair these activities causing enhanced cellular growth, neoangiogensis, and cancer development. ${ }^{8-10}$ Laboratory and epidemiological studies have implicated vitamin $D$ deficiency inthe pathogenesis of breast cancer. 1,25-Dihydroxy vitamin $D$ [1,25(OH)2D] promotes differentiation and apoptosis, and potently inhibits proliferation of malignant breast epithelial cells in culture. Serum levels of $1,25(\mathrm{OH}) 2 \mathrm{D}$ are higher in normal women than in patients with primary breast cancer. ${ }^{11}$ Women in Kurdistan of Iraq are thought to be at greater risk for vitamin $D$ deficiency because of the likelihood of reduced UV exposure due to socio-religious causes. However, data regarding this subject and its association with breast cancer risk is deficient. Therefore, we evaluated vitamin $\mathrm{D}$ concentration and explored its prognostic significance in patients with breast cancer as well as we determined whether the effects of vitamin $D$ differed among patients with various prognostic clinicopathological and immunohistochemical features of breast cancer such as grade, stage, hormone receptors status ER, PR (progesterone receptor) Her2neu (Human Epidermal Growth factor Receptor 2) immunoexpression, Ki-67 (proliferative activity) $\mathrm{PI}$ and molecular intrinsic subtypes.

\section{Methods}

The study is a prospective, populationbased case-control and case series study conducted in Erbil governorate. It is approved by the Scientific Research and Ethical Committees of the College of Medicine, Hawler medical university. During a six months period from $1^{\text {st }}$ September 2017 to $31^{\text {st }}$ March 2018, 50 female patients with histologically-proved breast cancer who diagnosed in the pathology department at Rizgary Teaching hospital and some private labs were enrolled as "breast cancer patients" after informed consent. All consenting patients were asked to complete a questionnaire about patient-related socio-demographic variables including age, education, occupational and residential history, physical activity, cigarette smoking, and alcohol consumption, medical history, reproductive history, family history of cancer, body size changes, dietary factors, use of complementary and alternative medicine and calcium and cholecalciferol intake. Postmenopausal status of females 
was defined as last menstrual bleeding at least 12 months before the date of the interview or a history of bilateral oophorectomy. Histological type, size, grade, stage, lymphvascular invasion were collected, and status of ER, PR, HER2neu, and $\mathrm{Ki}-67 \mathrm{PI}$ were determined through IHC staining that had been assessed by at least two pathology specialists. We used the American Joint Committee on Cancer staging system classification (AJCC 7th edition) for cancer staging ${ }^{12}$ and the Nottingham (Elston-Ellis) modification of the Scarff Bloom Richardson grading system for grading. ${ }^{13}$ After consent, blood samples were collected in vacutainers then allowed to clot for 20-30 min and centrifuged at $3000 \mathrm{Xg}$ for 20 minutes to separate the serum. For the case-control study, apparently healthy females were recruited as the "control group" and were identified from family members and friends of the patients or visitors to private labs or from volunteers recruited from the community. They were frequency matched to the expected age distribution of breast cancer patients on five years age category, marital status, BMI, menopausal status, residence (rural vs. urban) and month of blood collection in order to exclude the seasonal variations of 25-OHD concentrations due to change of solar ultra-violet B intensity. Exclusion criteria for both study groups were: non-Kurdish, concurrent or prior other type of malignancy, history of calcium or vitamin D supplements, chronic renal disease, liver disease, hyperthyroidism, malabsorption syndrome, or patients taking drugs as anticonvulsants, glucocorticoids, immunosuppressant. The American Society of Clinical Oncology/College of American Pathologists (ASCO/ CAP) guideline were followed for evaluation of IHC expression. ${ }^{14}$ It recommends that ER/ $\mathrm{PR}$ is considered positive if $1 \%$ or more of tumor cells have nuclear staining of any intensity whereas only intense and complete uniform membrane staining in $10 \%$ or more of the tumor cells were considered HER2/neu overexpression. For $\mathrm{Ki} 67$, nuclear staining of any intensity is considered positive and currently there is no standardized cutoff value for Ki67 PI in breast cancer; but a $14 \%$ was endorsed in St Gallen in 2011 for molecular subtyping. ${ }^{15}$

\section{Molecular subtyping of breast carcinoma}

Four molecular subtypes were defined depending on IHC analysis of ER, PR, HER2/neu and Ki $67 \mathrm{PI}$ as follows: luminal $\mathrm{A}$ (ER+ and/or PR+, HER2/neu- and Ki 67 $<14 \%$ ), luminal $\mathrm{B}$ (ER+ and/or $\mathrm{PR}+$, HER2/neu+ and Ki $67 \geq 14 \%$ ), HER2/neu enriched (ER-, PR- and HER2/neu+), and triple negative (ER-, PR- and HER2/ neu-). ${ }^{15}$

\section{Measurement of serum 25-OHD}

We based our statistical analyses on the storage form 25-OHD because this is the more abundant and stable form, and also because this is the commonly reported vitamin D assay technique. Biochemical blood measurements were determined by a standard laboratory procedure using COPAS e411, in which serum concentration of 25-OHD was measured by cobas e411 machine. The values were documented in $\mathrm{ng} / \mathrm{ml}$. Although no consensus on optimal levels of serum 25-OHD, vitamin $D$ deficiency was considered at serum level less than $20 \mathrm{ng} /$ $\mathrm{ml}$, vitamin $\mathrm{D}$ insufficiency was considered between 20 and $29 \mathrm{ng} / \mathrm{ml}$ and sufficient levels were $30 \mathrm{ng} / \mathrm{ml}$ and more in accordance with the reference values of our assays and internationally accepted concentration intervals. ${ }^{16}$

Statistical Analysis: We performed exploratory statistical analyses on the interrelatedness of various laboratory, clinical, and lifestyle variables by using the statistical package for the social sciences (version 23.0). The categorical demographic variables and the descriptive measures in breast cancer patients and controls were presented in frequency and percentages. The continuous variables were expressed as the mean \pm SD and 
range. Percent of categorical variables were compared using Pearson's Chisquare test or Fisher's exact test as appropriate. Relation of vitamin $D$ deficiency with grades, stages, histology, and receptor status of the tumor was determined by using the chi-square test. Comparison of mean vitamin $D$ levels among various histopathological parameters of tumor and comparison of vitamin $D$ levels between pre- and postmenopausal status was done by using a t-test and one-way Anova. All tests were two-sided. A $P$ value of $\leq 0.05$ was considered statistically significant.

\section{Results}

We performed two types of analyses. First, case-control analysis, where healthy controls were used as a referent group, and second, case-series analysis, where women with better prognostic characteristics (grade I/II, ER+, or luminal A subtype) were used as a referent group. The mean age of breast cancer patients was $51.1 \pm 10.7$ years and ranged between
$33-78$ years in which $52 \%$ of them were premenopausal females and $48 \%$ were postmenopausal females. Seventy two percent were multiparous, $84 \%$ had history of lactation and $82 \%$ had a BMI $\geq 25$. Regarding the occupational history, $86 \%$ of the breast cancer patients were house wives, and the majority (96\%) their dressing style was conservative. The mean of serum 25-OHD concentrations in breast cancer patients and controls were 8.138 \pm 7.5 and $16.7 \pm 12.06 \mathrm{ng} / \mathrm{mL}$, respectively with a highly statistical significant difference $(P<0.001)$. Eighty one percent of the controls were either vitamin $D$ deficient $(68 \%)$ or insufficient $(13 \%)$, and $(19 \%)$ of them had a sufficient level of 30 $\mathrm{ng} / \mathrm{mL}$ or higher. The proportion of vitamin $D$ deficiency and insufficiency was even higher in breast cancer patients $(96 \%)$, and only a very small proportion of them $(4 \%)$ was considered vitamin $D$ sufficient with a highly statistically significant correlation $(P=0.011)$ as shown in Table 1.

Table 1: Serum 25-OHD level in breast cancer patients and controls.

\begin{tabular}{lccccccc}
\hline & \multicolumn{2}{c}{ Breast cancer patients (cases) } & \multicolumn{2}{l}{ Healthy females (controls) } & \\
& Mean \pm SD & Min & Max & Mean \pm SD & Min & Max & $P$ value \\
\hline $\begin{array}{l}\text { Serum vitamin D } \\
\text { level (ng/ml) }\end{array}$ & $8.138 \pm 7.5$ & 3 & 33 & $16.7 \pm 12.06$ & 3 & 49 & $<0.001$ \\
Vitamin D category & $\mathrm{N}$ & $\%$ & $\mathrm{~N}$ & $\%$ & \\
Deficient & 45 & 90 & 68 & 68 & 0.011 \\
Insufficient & 3 & 6 & 13 & 13 & \\
Sufficient & 2 & 4 & 19 & 19 & \\
Total & 50 & 100 & 100 & 100 & \\
\hline
\end{tabular}


By taking mean season-standardized 25-OHD concentrations of the healthy controls to determine the cut-off point of vitamin $D$ levels in breast cancer patients for calculation the OR and $95 \% \mathrm{Cl}$ for risk association, we found that serum 25-OHD deficiency is positively associated with breast cancer OR $=4.1$ and $(1.68-10) 95 \%$ $\mathrm{Cl}$. After stratification of the breast cancer patients by menopausal status and in comparison with healthy controls, we found the serum 25-OHD deficiency was significantly associated with breast cancer risk in premenopausal $(P=0.004)$ more than postmenopausal status $(P=0.08)$; with an $\mathrm{OR}=7.5(95 \% \mathrm{Cl} 1.60-35.23)$ in premenopausal while OR $=2.714(95 \% \mathrm{Cl}$ $0.87-8.49$ ) in postmenopausal (Table 2).

Table 2: Odds ratios and $95 \%$ confidence interval for breast cancer by serum $25-\mathrm{OHD}$ levels for all, premenopausal and postmenopausal.

\begin{tabular}{|c|c|c|c|c|c|c|c|c|c|}
\hline \multirow{2}{*}{$\begin{array}{l}\text { Serum } \\
250 \mathrm{OH} \\
\text { levels }\end{array}$} & \multirow{2}{*}{$\begin{array}{l}\text { ALL } \\
\text { Breast } \\
\text { cancer } \\
\text { patients } \\
\text { N (\%) }\end{array}$} & \multirow[b]{2}{*}{$\begin{array}{c}\text { Control } \\
\text { N (\%) }\end{array}$} & \multirow[b]{2}{*}{$\begin{array}{c}\text { OR } \\
(95 \% \mathrm{Cl})\end{array}$} & \multicolumn{2}{|c|}{ Premenopausal } & \multirow[b]{2}{*}{$\begin{array}{c}\text { OR } \\
(95 \% \mathrm{Cl})\end{array}$} & \multicolumn{2}{|c|}{ Postmenopausal } & \multirow[b]{2}{*}{$\begin{array}{c}\text { OR } \\
(95 \% \mathrm{Cl})\end{array}$} \\
\hline & & & & $\begin{array}{c}\text { Breast } \\
\text { cancer } \\
\text { patients }\end{array}$ & $\begin{array}{c}\text { Control } \\
\text { N (\%) }\end{array}$ & & $\begin{array}{c}\text { Breast } \\
\text { cancer } \\
\text { patients } \\
\mathbf{N}(\%)\end{array}$ & $\begin{array}{c}\text { Control } \\
\text { N (\%) }\end{array}$ & \\
\hline Deficient & $43(86)$ & $60(60)$ & $\begin{array}{c}4.1 \\
(1.68-10 .)\end{array}$ & $24(92.3)$ & $\begin{array}{c}32 \\
(61.5)\end{array}$ & $\begin{array}{c}7.5(1.60- \\
35.23)\end{array}$ & $\begin{array}{c}19 \\
(79.2)\end{array}$ & $\begin{array}{c}28 \\
(58.3)\end{array}$ & $\begin{array}{c}2.7 \\
(0.87- \\
8.49)\end{array}$ \\
\hline $\begin{array}{l}\text { Non- } \\
\text { deficient }\end{array}$ & $7(14)$ & $40(40)$ & & $2(7.7)$ & $\begin{array}{c}20 \\
(38.5)\end{array}$ & & $\begin{array}{c}5 \\
(20.8)\end{array}$ & $\begin{array}{c}20 \\
(41.7)\end{array}$ & \\
\hline Total & $50(100)$ & $\begin{array}{c}100 \\
(100)\end{array}$ & & $26(100)$ & $\begin{array}{c}52 \\
(100)\end{array}$ & & $\begin{array}{c}24 \\
(100)\end{array}$ & $\begin{array}{c}48 \\
(100)\end{array}$ & \\
\hline$P$ value & & 0.001 & & & 0.004 & & & 0.080 & \\
\hline
\end{tabular}


For case-series analysis, the mean a significant statistical association was serum 25-OHD concentrations were correlated with selected demographic lifestyle characteristics (Table 3), present with the menopausal status clinicopathological (Table 4), and IHC (Table 5) prognostic criteria of breast cancer patients. Older women tended to have higher mean 25-OHD levels than younger women, although the differences were not statistically significant. However, $(P=0.05)$. Although BMl was not statistically correlated with circulating 25-OHD concentrations $(P=0.506)$, the higher BMI had a lower 25-OHD mean. No women had a history of vitamin D supplements, and a highly significant association presents with dressing style $(P=0.002)$.

Table 3: Mean serum 25-OHD concentration by demographic and clinical characteristics of breast cancer.

\begin{tabular}{|c|c|c|c|c|}
\hline Clinical characteristics & & $\mathbf{N}$ & MeantSD & $P$ value \\
\hline \multirow[t]{3}{*}{ Age } & & & & 0.128 \\
\hline & $<50$ & 23 & $6.4 \pm 4.5$ & \\
\hline & 350 & 27 & $9.6 \pm 9.1$ & \\
\hline \multirow[t]{4}{*}{ BMI } & & & & 0.506 \\
\hline & $<25$ & 9 & $10.6 \pm 9.1$ & \\
\hline & $25-30$ & 13 & $6.8 \pm 4.3$ & \\
\hline & $>30$ & 28 & $7.9 \pm 8.1$ & \\
\hline \multirow[t]{3}{*}{ Occupation } & & & & 0.568 \\
\hline & Indoor & 43 & $8.4 \pm 8$ & \\
\hline & Outdoor & 7 & $6.6 \pm 3.3$ & \\
\hline \multirow[t]{3}{*}{ Dressing type } & & & & 0.002 \\
\hline & Covered & 48 & $7.5 \pm 6.9$ & \\
\hline & Uncovered & 2 & $24 \pm 1.8$ & \\
\hline \multirow[t]{3}{*}{ Sun exposure } & & & & 0.256 \\
\hline & Exposed ( $\geq 30 \mathrm{mint})$ & 4 & $12.3 \pm 12.3$ & \\
\hline & Not $(<30 \mathrm{mint})$ & 46 & $7.8 \pm 7$ & \\
\hline \multirow[t]{3}{*}{ Marital status } & & & & 0.068 \\
\hline & Married & 42 & $9 \pm 7.9$ & \\
\hline & Single & 8 & $3.7 \pm 1.4$ & \\
\hline \multirow[t]{4}{*}{ Parity } & & & & 0.717 \\
\hline & No & 11 & $8.5 \pm 10.2$ & \\
\hline & $£ 2$ & 3 & $4.7 \pm 2.9$ & \\
\hline & $>2$ & 36 & $6.9 \pm 8.3$ & \\
\hline \multirow[t]{3}{*}{ Menopausal status } & & & & 0.054 \\
\hline & Pre menopause & 26 & $6.2 \pm 4.3$ & \\
\hline & Post menopause & 24 & $10.3 \pm 9.5$ & \\
\hline \multirow[t]{4}{*}{ Site } & & & & 0.370 \\
\hline & Left & 26 & $8.5 \pm 6.3$ & \\
\hline & Right & 21 & $7 \pm 7.4$ & \\
\hline & Both & 3 & $13.4 \pm 17$ & \\
\hline
\end{tabular}


Table 4: Mean serum 25-OHD concentrations by histopathologic prognostic characteristics in all, premenopausal and postmenopausal breast cancer patients.

\begin{tabular}{|c|c|c|c|}
\hline \multirow[t]{2}{*}{ Tumor criteria } & \multirow{2}{*}{$\begin{array}{c}\text { All } \\
(\mathrm{n}=50) \\
\mathrm{N}(\%) \text { mean } \pm \mathrm{SD} \\
P \text { value } \\
\end{array}$} & $\begin{array}{l}\text { Premenopausal women } \\
\qquad(n=26)\end{array}$ & \multirow{2}{*}{$\begin{array}{l}\text { Postmenopausal women } \\
\text { (n=24) } \\
\text { N(\%) mean } \pm \text { SD } \\
P \text { value }\end{array}$} \\
\hline & & $\begin{array}{c}\mathrm{N}(\%) \text { mean } \pm \mathrm{SD} \\
P \text { value }\end{array}$ & \\
\hline $\begin{array}{l}\text { Histologic type } \\
\text { IDC } \\
\text { Non-IDC }\end{array}$ & $\begin{array}{c}0.348 \\
46(92) \quad 8.4 \pm 7.7 \\
4(8) \quad 4.7 \pm 1.3\end{array}$ & $\begin{array}{rl} & 0.889 \\
24 & 6.22 \pm 4.49 \\
2 & 5.77 \pm 0.2\end{array}$ & $\begin{array}{cc} & 0.319 \\
22 & 10.85 \pm 9.73 \\
2 & 3.6 \pm 0.98\end{array}$ \\
\hline $\begin{array}{l}\text { Size } \\
<5 \mathrm{~cm} \\
\geq 5 \mathrm{~cm}\end{array}$ & 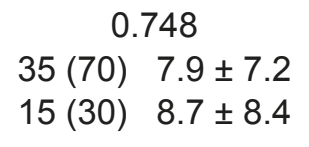 & $\begin{array}{ll} & 0.887 \\
16 & 6.09 \pm 4.77 \\
10 & 6.34 \pm 3.69\end{array}$ & $\begin{array}{ll} & 0.431 \\
19 & 9.45 \pm 8.59 \\
5 & 13.32 \pm 13.2\end{array}$ \\
\hline $\begin{array}{l}\text { Grade } \\
\text { I \&II } \\
\text { III }\end{array}$ & \begin{tabular}{cc}
\multicolumn{2}{c}{0.528} \\
$20(40)$ & $7.3 \pm 7.8$ \\
$30(60)$ & $8.7 \pm 7.4$
\end{tabular} & $\begin{array}{ll} & 0.061 \\
11 & 4.35 \pm 2.05 \\
15 & 7.53 \pm 5.05\end{array}$ & $\begin{array}{lc} & 0.797 \\
9 & 10.92 \pm 10.64 \\
15 & 9.85 \pm 9.15\end{array}$ \\
\hline $\begin{array}{l}\text { Stage } \\
\text { I \&II } \\
\text { III \& IV }\end{array}$ & $\begin{array}{c}0.937 \\
23(46) \quad 8.2 \pm 6 \\
27(54) \quad 8 \pm 8.7\end{array}$ & $\begin{array}{cl} & 0.055 \\
11 & 8.06 \pm 5.8 \\
15 & 4.81 \pm 4.31\end{array}$ & $\begin{array}{cc} & 0.347 \\
12 & 8.38 \pm 6.49 \\
12 & 12.13 \pm 11.82\end{array}$ \\
\hline $\begin{array}{l}\text { Lymph metastasis } \\
+\mathrm{ve} \\
\text {-ve }\end{array}$ & \begin{tabular}{cc}
\multicolumn{2}{c}{0.800} \\
$36(72)$ & $8.3 \pm 8.1$ \\
$14(28)$ & $7.7 \pm 6.1$
\end{tabular} & $\begin{array}{ll} & 0.905 \\
21 & 6.13 \pm 4.37 \\
5 & 6.40 \pm 4.51\end{array}$ & $\begin{array}{cc} & 0.478 \\
15 & 11.35 \pm 10.87 \\
9 & 8.42 \pm 6.92\end{array}$ \\
\hline
\end{tabular}

Table 5: Mean serum 25-OHD concentrations by IHC prognostic characteristics in all, premenopausal and postmenopausal breast cancer patients.

\begin{tabular}{|c|c|c|c|c|c|}
\hline \multirow[t]{2}{*}{$\begin{array}{l}\text { IHC } \\
\text { criteria }\end{array}$} & \multirow{2}{*}{$\begin{array}{c}\text { All } \\
(n=50) \\
N(\%) \text { mean } \pm \text { SD } P \text { value }\end{array}$} & \multicolumn{2}{|c|}{$\begin{array}{l}\text { Premenopausal women } \\
\qquad(n=26)\end{array}$} & \multicolumn{2}{|c|}{$\begin{array}{l}\text { Postmenopausal women } \\
\qquad(n=24)\end{array}$} \\
\hline & & $N(\%)$ & mean $\pm S D P$ value & $N(\%)$ & mean $\pm S D P$ value \\
\hline ER & 0.376 & \multicolumn{2}{|c|}{0.769} & \multicolumn{2}{|r|}{0.370} \\
\hline$+\mathrm{ve}$ & $34(68) \quad 8.8 \pm 8.5$ & 16 & $5.98 \pm 3.79$ & 18 & $11.28 \pm 10.59$ \\
\hline -ve & $16(32) 6.8 \pm 4.8$ & 10 & $6.5 \pm 5.23$ & 6 & $7.16 \pm 4.53$ \\
\hline PR & 0.496 & \multicolumn{2}{|c|}{0.146} & \multicolumn{2}{|r|}{0.784} \\
\hline +ve & 29 (58) $7.5 \pm 7.5$ & 14 & $5.04 \pm 2.38$ & 15 & $9.83 \pm 9.73$ \\
\hline -ve & $21(42) 9 \pm 7.6$ & 12 & $7.52 \pm 5.64$ & 9 & $10.96 \pm 9.7$ \\
\hline Her2 & 0.008 & \multicolumn{2}{|c|}{0.691} & \multicolumn{2}{|r|}{0.035} \\
\hline +ve & 29 (58) $5.8 \pm 3.6$ & 19 & $5.98 \pm 4.01$ & 10 & $5.50 \pm 2.89$ \\
\hline -ve & $21(42) \quad 11.4 \pm 10$ & 7 & $6.75 \pm 5.34$ & 14 & $13.65 \pm 11.17$ \\
\hline Ki-67 & 0.632 & \multicolumn{2}{|r|}{0.516} & \multicolumn{2}{|r|}{0.315} \\
\hline$<14$ & 16 (32) $8.9 \pm 7$ & 9 & $5.41 \pm 2.38$ & 7 & $13.36 \pm 8.61$ \\
\hline$\geq 14$ & 34 (68) $7.8 \pm 7.8$ & 17 & $6.59 \pm 5.06$ & 17 & $8.97 \pm 9.83$ \\
\hline $\begin{array}{l}\text { Molecular } \\
\text { types }\end{array}$ & 0.244 & \multicolumn{2}{|c|}{0.033} & \multicolumn{2}{|r|}{0.637} \\
\hline Luminal A & $7(14) 12.1 \pm 9.2$ & 2 & $5.5 \pm 3.53$ & 5 & $14.72 \pm 9.63$ \\
\hline Luminal B & $27(54) 7.9 \pm 8.2$ & 14 & $6.05 \pm 3.95$ & 13 & $9.96 \pm 11$ \\
\hline HER2/neu & $13(26) 5.6 \pm 3.3$ & 9 & $5.23 \pm 3.52$ & 4 & $6.37 \pm 3.13$ \\
\hline Triple -ve & $3(6) 11.8 \pm 7.8$ & 1 & $18.0 \pm 0$ & 2 & $8.74 \pm 8.12$ \\
\hline
\end{tabular}


When pre- and postmenopausal women with invasive breast cancer were considered together, there was no significant association between mean serum 25-OHD concentrations and all tumor pathological prognostic characteristics. After stratification of the breast cancer patients according to the menopausal status, there was a significant inverse relationship between serum 25OHD concentrations and tumor stage in premenopausal women $(P=0.05)$.

\section{Discussion}

There is a rising concern to recognize the magnitude of environmental, way of life and nutritional factors, and how these may act together with genetic susceptibility to modify risk of cancer occurrence, also there is raising data for a bond between vitamin $\mathrm{D}$ and protection against $\mathrm{BC}^{17}$ as numerous preclinical studies have shown that vitamin $D$ inhibits cell proliferation, induces differentiation and apoptosis, and has antiangiogenesis effects in normal and malignant breast cells. ${ }^{18,19}$ The mean serum level of vitamin D status differs from one country to another depending on various factors, including age, season, BMI, exposure to the sun, geographic location, dietary vitamin D intake, daily activity, and other ethnic and racial common factors. ${ }^{20}$ Measurement of circulating concentrations of 25-OHD provides an integrated measure of vitamin $D$ derived from all sources, including sunlight exposure, diet, and supplementation. It is considered the best indicator of vitamin $D$ body stores. ${ }^{5}$ Kurdistan of Iraq lies at latitudes of $36^{\circ} 11^{\prime} \mathrm{N}$ with good solar exposure, especially during summer. Despite that, we found that the mean serum vitamin $D$ in the healthy control group was $16.7 \mathrm{ng} / \mathrm{dl}$ and $68 \%$ were deficient below 20ng/dl. Our results lie within the range reported in other local and nearby literature that suggest; Low levels of vitD are the normal rather than an exception in developing countries especially in Asians. ${ }^{8,21-23}$ Where the prevalence of vitamin $D$ deficiency in healthy asymptomatic people is reported in the range of $60-97 \%$, which is twice that in western population ${ }^{24}$ and is more common in the urban population due to low sunlight exposure, high prevalence of various malabsorption syndromes in Asians, and the rare usage of vitamin $D$ supplementation. In breast cancer patients, the mean serum level of vitamin $D$ was $8.138 \mathrm{ng} / \mathrm{mL}( \pm 7.5 \mathrm{SD})$, which is significantly lower than in healthy controls $(P<0.001)$, and they were deficient in $90 \%$. Actually, vitamin $D$ deficiency in both study groups (breast cancer patients and controls) was expected and is no doubt attributable to the low sun rays exposure as the study was carried out in winter season, in addition to socio-religious conservative dress style practices and indoor life of women all over the year that does not facilitate adequate sun exposure together with the absence of vitamin $D$ fortified food. Due to the high prevalence of low vitamin $D$ in the healthy population, some epidemiological studies preferred to use $10 \mathrm{ng} / \mathrm{dl}$ as the cut off value for definition of vitamin $D$ deficiency instead of $20 \mathrm{ng} / \mathrm{dl}$ for assessment of its risk association with breast cancer, ${ }^{22,25}$ but we preferred to use mean seasonstandardized 25-OHD concentrations of the healthy controls to determine the cut-off point of vitamin $D$ levels in breast cancer patients for determination the relative risk association with breast cancer which was positive $(\mathrm{OR}=4.0952 ; 95 \% \mathrm{Cl}=$ 1.6760- 10.0066), specifically in premenopausal $(\mathrm{OR}=7.5 ; 95 \% \mathrm{Cl}=1.60-35.23)$ more than postmenopausal (OR= $2.7 ; 95 \% \mathrm{Cl}=0.87-8.49) ;$ moreover, premenopausal breast cancer females had lower mean serum levels of vitamin D compared to the postmenopausal females, and the results yielded borderline significance. These results parallel other studies from the developed world as United States, ${ }^{26}$ that showed $50-74 \%$ vitamin $D$ deficiency in newly diagnosed premenopausal breast cancer patients, 
and developing countries ${ }^{9,22,25}$ that concluded; low serum levels of vitamin $D$ are common at breast cancer diagnosis and are associated with a poorer prognosis in terms of overall survival and distant disease free survival and have suggested an inverse correlation between 25-OHD levels and risk of breast cancer, though these results differ according to study design. $^{27,28}$ Despite the positive relative risk association between breast cancer and vitamin $\mathrm{D}$ deficiency, it cannot reveal which one is preceding the other as both of them detected at the same time. In addition; Because of ethnic and racial variations in serum vitamin $D$ levels, the optimal circulating level of 25-OHD for reducing breast cancer risk or reducing the risk of recurrence has yet to be defined and the relevant time period during which $25-\mathrm{OHD}$ levels may affect breast cancer occurrence or survival is currently unknown. ${ }^{20}$ More than three quarter of breast cancer patients $(82 \%)$, their BMI was above the expected normal level. revealing an additional small but sinister causal link of low vitamin D levels with high BMI in breast cancer patients. Lower serum levels of vitamin D have been associated with obesity and lower physical activity in various epidemiological studies ${ }^{29,30}$ because body fat holds onto vitamin $D$ tenaciously and does not release it efficiently. In the case series analysis, mean serum levels of vitamin $D$ did not correlate inversely with most histopathological prognostic criteria as size, grade, histological type, and lympho-vascular invasion of breast cancer; probably due to relatively small size of the study population. However, a significant inverse association with tumor stage in premenopausal was found $(P=0.055)$, which simulate others. ${ }^{8,25}$ Regarding the IHC receptor expression of breast cancer (ER, PR, Her2/neu and $\mathrm{KI} \mathrm{PI}$ ) and the molecular subtyping (luminal types $A$ and $B$, triple negative or Her2/neu enriched); all had deficient mean vitamin $D$ levels; but there was a difference of statistical importance with positive Her2/neu immunoexpression in all $(P=0.008)$ and particularly postmenopausal $(P=0.035)$. Moreover, Her2/ neu enriched molecular subtype had the lowest mean serum vitamin $D$ with statistical significance in premenopausal $(P=0.033)$. Her $2 / \mathrm{neu}$, is a transmembrane tyrosine kinase receptor that binds to its extracellular signals and initiates a signaling cascade mediating cell proliferation and survival, its overexpression is long known to have contribution to aggressive behavior of breast cancer with poor outcomes ${ }^{31}$ and Her2/neu enriched subtype of breast cancer has been also shown to have unfavorable prognosis as compared to the luminal types. ${ }^{32,33}$ Because of antiproliferative and protective effect of vitamin $D$ on cancer cells, its deficiency implies higher proliferation in cancer cells with more expression of proliferative genes and this could explain lower levels of vitamin $D$ in the Her2/neu enriched molecular subtype. Contrary to our study, a study by $\mathrm{Kim}$ et al., ${ }^{34}$ from Korea has shown the relation of vitamin $\mathrm{D}$ deficiency with poor prognosis of luminal types. However, no relation was shown with her2/neu enriched and they found triple-negative subtype has the highest percentage of vitamin $D$ deficiency. They have hypothesized that it may be due to suppressing and antiproliferative effect of vitamin $D$ on estrogen-mediated breast cancer that are ER positive, i.e. luminal type, but they have not explained any mechanism for ER negative cancers. Actually, several epidemiologic studies have shown conflicting results between vitamin $D$ and hormone receptor-defined breast cancer. Increased intake of vitamin D was found to be consistently associated with a significantly reduced risk of ER+/PR+ tumors, and dietary vitamin $\mathrm{D}$ level was inversely related to the risk of ER+ tumors. $^{35,36}$ However, a Japanese study reported that ER+ and/or PR+/Her2- breast cancer frequency was significantly associated with vitamin $D$ intake in premenopausal women. ${ }^{37}$ As a result, 
further studies explaining the exact molecular mechanism underlying such observations need to be carried out. The drawbacks of the current study include the limited time and the small sample size collected from a single ethnic and geographical area. Also, serum 25-OHD levels are reflective of a recent and not lifetime vitamin $\mathrm{D}$ intake; hence one single measurement of vitamin $D$ levels may not be reflective of long term exposure. Therefore, further studies considering these aspects must be carried out. However, to the best of our knowledge, this is the first study in Kurdistan of Iraq, evaluating the prognostic effect of vitamin $D$ deficiency in breast cancer and taking into account the molecular subtypes of breast cancer.

\section{Conclusion}

These results add to a growing body of evidence that vitamin $D$ deficiency associated with breast cancer risk and prognosis. As a result, dietary vitamin D and casual sunlight exposure will be among the modifiable risk factors for breast cancer and well-designed clinical trials are highly needed to determine whether vitamin $D$ supplementation is effective for breast cancer chemoprevention and prognosis improvement if occur.

\section{Competing interests}

The authors declare no competing interests.

\section{References}

1. Siegel RL, Miller KD, Jemal A. Cancer statistics. CA Cancer J Clin 2016; 66:7-30.

2. Alwan N. Iraqi Initiative of a Regional Comparative Breast Cancer Research Project in the Middle East. J Cancer Biol Res 2014; 2(1):1016.

3. Othman RT, Abdulljabar R, Saeed A, Kittani SS, Sulaiman HM, Mohammed SA, et al. Cancer incidence rates in the Kurdistan region/Iraq from 2007-2009. Asian Pac J Cancer Prev 2011; 12(5):1261-4.

4. Haq A, Sofi NY. Vitamin D and breast cancer: Indian prespective. Clinical Nutrition Experimental 2017; 12:1-10.

5. Crew KD, Gammon MD, Steck SE, Hershman
DL, Cremers S, Dworakowski E, et al. Association between plasma25- hydroxyvitamin D \& breast cancer risk. Cance Prev Res 2009; 2(6):598-604.

6. Garland CF, Gorham ED, Mohr SB, Garland FC. Vitamin D for cancer prevention: Global perspective. Ann Epidemiol 2009; 19:468-83.

7. Lappe JM, Travers-Gustafson D, Davies KM, Recker RR, Heaney RP. Viatmin D and calcium supplementation reduces cancer risk: Results of a randomized trial. Am Clin Nutr 2007; 85:158691.

8. Imtiaz S, Siddiqui N, Raza SA, Loya A, Muhammad A. Vitamin D deficiency in newly diagnosed breast cancer patients. Indian J Endocrinol Metab 2012; 16(3): 409-13.

9. Elizabeth R, Bertone-Johnson SD. Vitamin D and Breast Cancer. Ann Epidemiol 2009; 19(7):4627.

10. Colston KW, Hansen CM. Mechanisms implicated in the growth regulatory effects of vitamin $D$ in breast cancer. Endocr Relat Cancer 2002; 9:45-59.

11. Palmieri C, MacGregor T, Girgis S, Vigushin D. Serum 25-hydroxyvitamin D levels in early and advanced breast cancer. J Clin Pathol 2006; 59(12):1334-6.

12. Edge SB, Compton CC. The American Joint Committee on Cancer: The 7th edition of the AJCC cancer staging manual and the future of TNM. Ann Surg Oncol 2010; 17:1471-4.

13. Pradhan A, Paudyal P, Sinha AK, Agrawal CS. Grading, staging and Nottingham prognostic index scoring of breast carcinoma. Journal of Pathology of Nepal 2017; 7:1078-83.

14. Hammond ME, Hayes DF, Dowestt M, Allred DC, Hagerty KL, Badve S, et al. American Society of Clinical Oncology/College of American Pathologists guideline recommendations for immunohistochemical testing of estrogen and progesterone receptors in breast cancer (unabridged version). Arch Pathol Lab Med 2010; 134(7):e48-72.

15. Goldhirsch A, Wood WC, Coates AS, Gelber RD, Thutlimann B, Senn HJ, et al. Strategies for subtyped of dealing with the diversity of breast cancer-highlights of the St. Gallen International Expert Consensus on the primary therapy of early breast cancer 2011. Ann Oncol 2011; 22(8):1736-47.

16. Ringe JD, Kipshoven C. Vitamin D-insufficiency: An estimate of the situation in Germany. Dermato -endocrinology 2012; 4(1):72-80.

17. Colston KW. Vitamin $D$ and breast cancer risk. Best Pract Res Clin End Met 2008; 22:587-99.

18. Moukayed M, Grant WB. Molecular link between vitamin D and cancer prevention. Nutrition 2013; 5(10):3993-4021.

19. Welsh J. Vitamin D and breast cancer: insights from animal models. Am J Clin Nutr 2004; $80: 1721 S-4 S$. 
20. Khan QJ, Kimler BF, Fabian CJ. The relationship between vitamin $D$ and breast cancer incidence and natural history. Curr Oncol Rep 2010; 12:136 -42 .

21. Al-Hilali K A. Prevalence of Hypovitaminosis D in Adult Iraqi People Including Postmenopausal Women. SCIRJ 2016; 4(9):53-62.

22. Yousef FM, Jacobs ET, Kang PT, Hakim IA, Going S, Yousef JM, et al. Vitamin D status and breast cancer in Saudi Arabian women: casecontrol study. Am J Clin Nutr 2013; 98:105-10.

23. Arabi A, El Rassi R, El-Hajj Fuleihan G. Hypo-vitaminosis D in developing countriesprevalence, risk factors and outcomes. Nat Rev Endocrinol 2010; 6(10):550-61.

24. Spiro A, Buttriss J L. An overview of Vitamin D status and intake in Europe. Nutr Bull 2014; 39(4):322-50.

25. El-Shorbagy S, Haggag R, Ebian HF, Labib HA, Harb OA. Prognostic Impact of 25-Hydroxyvitamin D Levels in Egyptian Patients with Breast Cancer. J Cancer Sci Ther 2017; 9:496-502.

26. Khan QJ, Fabian CJ. How I treat vitamin D Deficiency. JOP 2010; 6:97-100.

27. Yin L, Grandi N, Raum E. Meta-analysis: Serum vitamin $\mathrm{D}$ and breast cancer risk. Eur J Cancer 2010; 64(12):2196-205.

28. Vrieling A, Hein R, Abbas S, Schneeweiss A, Flesch-Janys D, Chang-Claude J. Serum 25hydroxy vitamin D and postmenopausal breast cancer survival: A prospective patient cohort study. Breast Cancer Res 2011; 13(4):R74.

29. Napoli N, Vattikuti S, Ma C, Rastelli A, Rayani A, Donepudi R, et al. High prevalence of low vitamin $\mathrm{D}$ and musculoskeletal complaints in women with breast cancer. Breast J 2010; 16:609-16.

30. Camacho PM, Dayal AS, Diaz JL, Nabhan FA, Agarwal M, Norton JG, et al. Prevalence of secondary causes of bone loss among breast cancer patients with osteopenia and osteoprosis. $\mathrm{J}$ Clin Oncol 2008; 26:5380-5.

31. Slamon DJ, Clark GM, Wong SG, Levin WJ, Ullrich A, McGuire RL. Human breast cancer: correlation of relapse and survival with amplification of the HER-2/neu oncogene. Science 1987; 235:177-82.

32. Smail A, El-Awady R, Mohamed G, Hussein M, Ramadan SS. Prognostic Significance of Serum Vitamin D Levels in Egyptian Females with Breast cancer. Asian Pac J Cancer Prev 2018 26; 19(2):571-6.

33. Lukong KE. Understanding breast cancer - The long and winding road. BBA Clinical 2017; 7:6477.

34. Kim HJ, Lee YM, Ko BS, Lee JW, Yu JH, Son $\mathrm{BH}$, et al. Vitamin $\mathrm{D}$ deficiency is correlated with poor outcomes in patients with luminal type breast cancer. Ann Surg Oncol 2011; 18:1830-6.

35. Blackmore KM, Lesosky M, Barnett H, Raboud JM, Vieth R, Knight JA. Vitamin D from dietary intake and sunlight exposure and the risk of hormone-receptor-defined breast cancer. Am J Epidemiol 2008; 168(8):915-24.

36. McCullough ML, Rodriguez C, Diver WR, Feigelson HS, Stevenes VL, Thun MJ, et al. Dairy, calcium, and vitamin D intake and postmenopausal breast cancer risk in the Cancer Prevention Study II Nutrition Cohort. Cancer Epidemiol Biomarkers Prevent 2005; 14(12):2898 $-904$.

37. Kawase T, Matsuo K, Suzuki T, Hirose K, Hosono S, Watanabe A, et al. Association between vitamin $D$ and calcium intake and breast cancer risk according to menopausal status and receptor status in Japan. Cancer Sci 2010; 101(5):1234-40. 